\title{
STOSOWANIE METAFOR JAKO WYRAZ KOMPETENCJI KOMUNIKACYJNEJ U WYBRANYCH PISARZY WCZESNOCHRZEŚCIJAŃSKICH
}

Metafory starożytnych pisarzy chrześcijańskich są dowodem niewątpliwie wielkiego kunsztu i kompetencji komunikacyjnej, jakie posiadali starożytni autorzy chrześcijańscy. Zapoznając się z ich sposobami wyrażania się, jesteśmy wprowadzani do interesującego świata komunikacji religijnej, jej języka, stosowanych technik retorycznych. Tak sformułowany temat zasługuje na obszerne opracowanie jednak w niniejszym badaniu zostanie ograniczony do kilkunastu wybranych metafor na temat ubóstwa i bogactwa skomponowanych i użytych przez wczesnochrześcijańskich pisarzy nazywanych Ojcami Kościoła.

Ludwig Wittgenstain wyraził i zapisał słynne już i inspirujące zdanie, że „granice mego języka oznaczają granice mego świata”. W tym zdaniu zawarta jest myśl, że to właśnie język, w dużej mierze, umożliwia nam zarówno poznanie jak i odkrywanie świata. Posługując się językiem, mówimy także metaforami (chodzi o metafory pojęciowe), choć tego często nie zauważamy. Dane statystyczne podają, że przeciętnie na minutę mówienia przypada sześć metafor. Nasze codzienne rozmowy są wypełnione tą interesującą strukturą lingwistyczną czy inaczej retorycznym narzędziem. ${ }^{2}$ Wystarczy przyjrzeć się naszemu mówieniu i stosowanym przez nas wyrażeniom, by się przekonać, że wiele z naszych sformułowań zostało zbudowanych na przenośni, na metaforze.

1 L. W it t g e n s t a i n, Tractatus Logico-Philosophicus, tłum. B. W o $1 \mathrm{n}$ i e w i c z, Warszawa 1970, s. 67.

2 M. Pas ter s k i, Metafory w rozmowie, http://michalpasterski.pl/2010/09/ metafory-w-rozmowie/ (dostęp 18 V 2014 r.). 
Czy filiżanka coś słyszy? A przecież mówimy, że ma ucho. Czy oczko w pończosze coś widzi? A przecież mówimy, że jest oczko. Czy stół gdzieś nam ucieknie? A przecież mówimy, że ma nogi. Czy rakieta tenisowa wystartuje w powietrze? A przecież nazywamy ją rakietą. Czy język może być ostry? A przecież mówimy „on to ma ostry język“. To przykłady tylko na jeden typ metafory, często spotykany w „niepoetyckim“ języku: typ tzw. katachreza, czyli rozszerzenie znaczenia. Metaforami posługujemy się często, określając swoje samopoczucie. Jeśli ktoś mówi: „Jestem w dołku i nie mogę ruszyć z miejsca” to dopóki ta osoba rzeczywiście nie wpadła do dołu w ziemi, z którego nie może wyjść, prawdopodobnie określa ona właśnie sytuację w swoim życiu prywatnym, rodzinnym, zawodowym. Jest to metafora oddająca stan samopoczucia, a nie to, że fizycznie stoi w dole, który wykopali robotnicy remontujący drogę. Jeśli ktoś mówi, że czuje się jakby ,dostał skrzydła” to nie znaczy, że mu w ostatniej nocy fizycznie urosły skrzydła, ale że czuję się lekko, tak jakby fruwał, ma jakieś dodatkowe siły i radość życia, która niesie go w górę. I wiele innych metafor takich jak: ,noszę na sobie wielki ciężar“, ,zamurowało mnie“, „nie nadajemy na tych samych falach“ czy „czuję się jak na tureckim kazaniu“ komunikuje nasze stany emocjonalne, uczucia i nastawienie. ${ }^{3}$ Te wszystkie wyrażenia i sformułowania to metafory.

Badacze tej dziedziny języka twierdzą, że „prawie wszystko to, co wiemy, łącznie z poważną nauką, opiera się na metaforze“ - to słowa prof. Josepha Weizenbauma. ${ }^{4}$ W 1980 r. George Lakoff wraz z Markiem Johnsonem wydali książkę Metafory w naszym życiu, w której dowodzą, że metafora stoi w centrum międzyludzkiej komunikacji. Bez użycia metafor komunikacja międzyludzka byłaby niemożliwa. ${ }^{5}$ Uważają, że całe nasze myślenie jest metaforyczne, że język sam w sobie jest metaforyczny. A metafora jest wynalazkiem na miarę koła, które jakościowo zmieniło życie i sposób przemieszczania się ludzi.

\footnotetext{
Tamże.

J. W e i z e n b a u m, Moglibyśmy mieć raj, Forum z dn. 28 I 2008.

G. L a k off, M. J o h n s o n, Metafory w naszym życiu, Warszawa 1988,
} s. 25 . 


\section{Wprowadzenie metodologiczne}

W niniejszym artykule stawiam następujące pytania badawcze: Co możemy powiedzieć o kompetencji komunikacyjnej Ojców Kościoła w kontekście stosowanych przez nich metafor? Za pomocą jakich metafor Ojcowie Kościoła przedstawiali ubóstwo lub bogactwo? Jak starożytni pisarze chrześcijanie postrzegali ubóstwo? Co możemy o tych metaforach powiedzieć z punktu widzenia retoryki i komunikacji religijnej? Co Ojcowie Kościoła przez te metafory komunikują ludziom w XXI w.? Co mogą zaproponować współczesnemu przekazowi wiary Ojcowie Kościoła?

Zdecydowano się przedstawić jedną z często stosowanych przez Ojców Kościoła technik retorycznych, jaką jest metafora. Na potrzeby artykułu zostało przebadanych wielu słynnych starożytnych mówców i pisarzy chrześcijańskich w celu znalezienia w ich pismach, homiliach i kazaniach metafor dotyczących tematu ubóstwa i bogactwa.

W pierwszej kolejności wyjaśniono, czym jest metafora, jaką pełni funkcje, czyli jak działa metafora. Następnie zaprezentowano wybrane metafory Ojców Kościoła na temat ubóstwa i bogactwa wraz $\mathrm{z}$ ich interpretacją, a na koniec podsumowano prezentowany temat i przedstawiono wnioski dotyczące ich umiejętności komunikacyjnych i retorycznych.

$\mathrm{Na}$ kanwie tego można zaproponować kilka wytycznych odnoszących się współczesnego przekazu wiary i komunikacji religijnej.

\section{Czym jest metafora?}

Jako pierwszy zajął się naukowo metaforą i określił, czym ona jest, Arystoteles. Dla niego metafora, mówiąc najkrócej, „to przeniesienie nazwy jednej rzeczy na inną". ${ }^{6}$ Mówiąc o jednej rzeczy, mówi się właściwie o drugiej. Dane wyrażenie, właściwe dla oznaczenia jednego przedmiotu, zostaje odniesione do jakiegoś innego,

${ }^{6}$ A rystoteles, Poetyka w: te n że, Retoryka. Poetyka, tłum. H. Podb i e 1 s k i, Warszawa 1988, s. 351. 
dla którego, per se, wyrażenie to zostało utworzone. ${ }^{7}$ Przykład metafory: „Nikt nie jest samotną wyspą“. Przenosimy jedną nazwę, a mianowicie ,samotna wyspa“" na drugą nazwę, w tym przypadku na „człowieka“ - twierdząc, że człowiek z natury jest istotą społeczną, a nie samotnikiem. Taki jest sens tej metafory.

Według Georga Lakoffa, w skrócie metaforę można ująć następująco: to, co bardziej abstrakcyjne, wyraża się przez to, co mniej abstrakcyjne. ${ }^{8}$ C.S Lewis uważa, że kiedy mówi się o rzeczach, których nie można dotknąć ani zobaczyć, trzeba mówić o tym tak, jak gdyby było możliwe ich zobaczenie lub dotknięcie. ${ }^{9}$ Święty Tomasz z Akwinu natomiast stawia pytanie: „Czy Pismo Święte winno używać przenośni?““I odpowiada: „Całkiem słusznie w Piśmie Świętym podano nam sprawy duchowe pod przenośniami rzeczy cielesnych“. ${ }^{10}$ Całe poznanie człowieka zaczyna się od poznania zmysłowego. „Przez to, co poznawalne zmysłami, człowiek dochodzi do tego, co jest uchwytne już tylko rozumem. Dlatego w Piśmie Świętym to, co duchowe, jest nam w sposób odpowiedni podawane za pomocą metafor z dziedziny materialnej". ${ }^{11} \mathrm{~W}$ słownikach na temat metafory czytamy: „Metafora to figura retoryczna (figura stylistyczna), postać mowy, środek ekspresji językowej polegający na stosowaniu ozdobnych zwrotów i wyrażeń". ${ }^{12}$

7 A. P a c i o r e k, Alegoria i teoria w egzegezie starożytnego Kościoła, Colectanea Theologica 67(1997)1, s. 57-78.

8 G. L a k o f f, The Contemporary Theory of Metaphor, w: A. O r t o n y (red.), Metaphor and Thought, Cambridge 1993, s. 207.

9 C. S. L e w i s, Listy starego diabła do młodego, Warszawa 1993, s. 24.

10 Św. To mas z z A k w in u, Suma teologiczna. O Bogu, cz. I, I, 1,9, tłum. P. B ełc h, Londyn 1975, s. 70-71.

11 Tamże.

12 S. D u b i s z (red.), Uniwersalny stownik języka polskiego, t. 2, Warszawa 2003, s. 612; B. D u n a j (red.), Słownik współczesny języka polskiego, Warszawa 1996, s. 507; J. W o j n ow s k i (red.), Wielka encyklopedia PWN, t. 17, Warszawa 2003, s. 280-281. 


\section{Jak działają metafory?}

Wiemy, czym jest metafora. Jest figurą retoryczną, sposobem wyrażania myśli i przeżyć. Przenosi znaczenie jednej rzeczy na drugą. Teraz zapytajmy, jak działają metafory. Jaka jest ich funkcja? Metafory porządkują nasze działania, rządzą naszymi myślami i uczuciami. Kryją w sobie siłę przekonywania innych do czegoś. Przenoszą nas z płaszczyzny tylko świadomej na podświadomą, z płaszczyzny tylko intelektualnej na emocjonalną i uczuciową. Jak powie Jung, dotykają w człowieku takiego miejsca, do którego nie dociera język abstrakcyjny, a tylko obrazowy. ${ }^{13}$ Metafora porusza całego człowieka: jego myślenie, wyobraźnię, uczucia, pamięć, ciało uderza we wszystkie sfery natury ludzkiej. Łączy to, co niewidzialne, z tym, co widzialne, to, co abstrakcyjne, z tym, co konkretne. Innymi słowy metafora jest mostem między percepcją, a wyobraźnią. Przesuwa znaczenie czegoś, kogoś, jakiś stanów i zjawisk w świat wyobraźni. Przenosi coś z jednego miejsca na drugie. Wciąga odbiorcę w tworzenie znaczenia. Powoduje pewną dynamikę, pewne działanie odbiorcy, stwarza swoistą energię myślową i uczuciową w całym procesie komunikacji międzyludzkiej. Przenosi w przestrzeń sztuki. Sama staje się jak dzieło sztuki - jak obraz, który rodzi uczucia i porusza myśl. Metafora łamie reguły statycznego znaczenia i otwiera drzwi do nowych, świeżych znaczeń.

\section{Kompetencja komunikacyjna}

Konstruowanie i używanie metafor jako środka ekspresji językowej wchodzi w zakres komunikacji językowej, która z kolei jest integralną częścią kompetencji komunikacyjnej. Umiejętność konstruowania adekwatnych i poprawnych gramatycznie zdań uwarunkowana jest licznymi czynnikami. Jednym $\mathrm{z}$ istotnych jest uwzględnienie przez mówcę czy rozmówcę uwarunkowań danej sytuacji komunikacyjnej

13 J. J a c o b i, Psychologia C.G. Junga. Wprowadzenie do całości dzieła, Warszawa 1993, s. 69-70. 
i dostosowywania do niej werbalnych i pozawerbalnych komunikatów. ${ }^{14} \mathrm{~W}$ ujęciu definicyjnym owa „kompetencja komunikacyjna to świadoma lub nieuświadamiana wiedza o regułach używania języka w różnych sytuacjach stwarzanych przez daną wspólnotę społeczną". ${ }^{15}$

W trakcie rozwoju badań nad kompetencją komunikacyjną wyróżniono w niej i przedstawiono integralne części, takie jak: kompetencję pragmatyczną jako zdolność nadawcy lub/i odbiorcy do zrozumiałego wyrażania się w różnych sytuacjach komunikacyjnych; kompetencję socjolingwistyczną jako znajomość wszystkich reguł używania języka w zależności od sytuacji i roli społecznej oraz kompetencję językową związaną ze znajomością języka pozwalającą rozumieć i budować coraz to nowe zdania i wyrażenia. ${ }^{16} \mathrm{~W}$ dokumencie Rady Europy zatytułowanym Europejski system opisu kształcenia językowego czytamy, że na kompetencje użytkownika języka składają się kompetencje ogólne oraz komunikacyjne kompetencje językowe, tworzone przez składniki: socjolingwistyczny, lingwistyczny i pragmatyczny. ${ }^{17}$ Według wspomnianego wyżej tekstu, „stosowanie językowej kompetencji komunikacyjnej przejawia się w działaniach językowych, czyli w rozumieniu i tworzeniu tekstów/wypowiedzi, działaniach interakcyjnych i mediacyjnych". ${ }^{18} \mathrm{~W}$ zaproponowanym przez Radę Europy ujęciu kompetencji komunikacyjnej wynika, że jej najważniejszym elementem jest aspekt pragmatyczny. Składnik ten „obejmuje wiedzę, kompetencję egzystencjalną i umiejętności odnoszące się do tego, co przy pomocy systemu lingwistycznego

14 T. S i e k - P i s k o z u b, Międzykulturowa kompetencja komunikacyjna wyzwaniem dla glottodydaktyki, Lingwistyka Stosowana 5 /2012, s. 95-97.

15 A. S k u d r z y k ow a, K. U r b a n, Mały słownik terminów z zakresu socjolingwistyki i pragmatyki językowej, Kraków-Warszawa 2000, s. 86.

16 Tamże.

${ }_{17} \mathrm{R}$ a d a E u ro p y, Europejski system opisu kształcenia językowego: uczenie sie, nauczanie, ocenianie, Warszawa 2001, s. 99-106.

18 Tamże, s. 24. 
w jego zróżnicowanych wariantach socjolingwistycznych można osiągnąć w komunikacji”. ${ }^{19}$

Pisarze starochrześcijańscy, jak wynika z przeprowadzonych na potrzeby tego artykułu badań, wykazują się wszystkimi trzeba składnikami aspektu pragmatycznego kompetencji komunikacyjnej, a mianowicie: ogromną wiedzą, kompetencją egzystencjalną oraz umiejętnością lingwistyczną w jej zróżnicowanych wariantach socjolingwistycznych. Ojcowie Kościoła to bardzo często wielcy mówcy i pisarze, którzy kształcili się w słynnych szkołach retorycznych, jakie wówczas istniały. Analizując ich mowy i dzieła, łatwo zauważyć kompetencję językową i komunikacyjną, jaką się wykazują. Analizowane i przedstawione wybrane metafory ubóstwa są tego dowodem.

\section{Przykłady metafor ubóstwa lub bogactwa}

Przechodzimy teraz do wybranych metafor ubóstwa lub bogactwa stosowanych przez Ojców Kościoła w ich wybranych dziełach i wypowiedziach. Zapytamy, na tym etapie, o znaczenie i siłę perswazji tychże metafor oraz ich walor komunikacyjny.

\section{Ubóstwo podobne jest do pięknej kobiety}

„Nie uważaj ubóstwa za coś ciężkiego", nawołuje Jan Chryzostom (350-407). I dokonuje pochwały ubóstwa. „Ubóstwo podobne jest do pięknej, urodziwej i ubranej panny, chciwość natomiast do kobiety o kształcie dzikiego zwierza, i do innych jeszcze potworów zmyślonych przez mitologów". ${ }^{20} \mathrm{~W}$ dalszej części tej homilii Chryzostom zachęca do przyjrzenia się tej pannie i mówi: „Obejrzyjmy piękność

19 B. G r o c h a l a, Kompetencja komunikacyjna a gatunek - o relacji internetowej na żywo, Acta Universitatis Lodziensis Kształcenie polonistyczne cudzoziemców 20/2013, s. 304.

${ }^{20}$ Jan Chryzost o m, Homilia 90, 4: Mt 28,11-20, zob. te nż e, Homilie na Ewangelię wedtug św. Mateusza, cz. II, 41-90, tłum. A. B a r o n, J. K r y s t y n i a c k i, ŹMT 23, Kraków 2001, s. 530-531. 
tejże panny. Jej oko jest czyste $\mathrm{i}$ jasne, nie ma w sobie nic niespokojnego, jak płonące gniewem oko chciwości(...). Oko ubóstwa jest łagodne, spokojne, spogląda na wszystkich mile, jest przyciągające i przyjemne, nikogo nienawidzi, od nikogo się nie odwraca (...). Usta ubóstwa są zdrowe, nieustannie są na nich dziękczynienia, błogosławieństwa, słowa łagodne, uprzejme, pokorne, pełne pochwał i uznania. A gdybyś chciał jeszcze poznać układ jej ciała to jest ona wysokiego wzrostu i wyższa od bogactwa”. Jak kończy swoją homilię Chryzostom? „Czy ty nie możesz go rozdać? [bogactwo, majątek uwaga K. M.]. Oczywiście, że możesz! Ale ja cię nie zniewalam ani nie zmuszam, jeśli nie chcesz. Proszę cię jedynie o to, abyś dawał ubogim choć część i abyś nie starał się o nic więcej ponad konieczną potrzebę. W ten sposób i tu będziemy wiedli życie spokojne i bezpieczne, i dostąimimy życia wiecznego". ${ }^{21}$

Mamy tutaj do czynienia z metaforą, w której Jan Chryzostom bierze obraz pięknej kobiety, czyli konkretny, doświadczalny obraz, i przenosi go na bóstwo - rzeczywistość bardziej abstrakcyjną. Wykorzystuje oczy, usta i sylwetkę pięknej kobiety i przenosi je na wyjaśnienie ubóstwa. Oczy ubogiego są spokojne i piękne jak oczy pięknej kobiety. Sylwetka ubogiego, jego osobowość, jest zgrabna i zwiewna jak sylwetka pięknej kobiety. Twarz ubogiego jest twarzą piękną. Cechy konkretnego obrazu są przenoszone na rzeczywistość bardzej abstrakcyjną, tę, którą chcemy wyjaśnić, tę, do której chcemy przekonać. Tym samym Chryzostom wykorzystuje siłę perswazji, jaka tkwi w tym obrazie, który kojarzy się z czymś pięknym, przyjemnym, przyciągającym. W ten sposób zachęca i przekonuje do wyboru ubóstwa w naszym życiu.

21 Homilia 90, 4: Mt 28,11-20, zob. Ja n C h r y z o s t o m, Homilie na Ewangelie, s. 532-533. 


\section{Ubóstwo to spokojny port}

Jan Chryzostom w homilii na Ewangelię według św. Mateusza porównuje ubóstwo do spokojnego i bezpiecznego portu. ${ }^{22}$ Jego logika wywodu jest taka, że wszyscy uganiamy się za bezpiecznym życiem, za bezpieczeństwem w życiu. Powszechnie się uważa, że bogactwo da nam bezpieczeństwo. Chryzostom pyta w homilii: „Jak to możliwe - zapytasz - zabezpieczyć je sobie bez bogactwa? A ja zapytam wprost przeciwnie: Jak to możliwe, osiągnąć je wraz z bogactwem?" I kontynuuje: „Trzeba bowiem schlebiać wielu ludziom, zwierzchnikom i poddanym, starać się o rozliczne rzeczy, pełnić niegodną, niewolniczą służbę, bać się i drżeć, podejrzewać wzrok pochlebców, lękać się ust donosicieli i zachłanności innych chciwców. W ubóstwie zaś nie ma niczego podobnego, ale wszystko jest przeciwne. Ubóstwo jest miejscem niedostępnym i bezpiecznym, spokojnym portem". ${ }^{23}$ Chryzostom wykorzystuje tutaj obraz spokojnego portu, który rodzi wiele myśli i obrazów. Port zawsze kojarzy się z domem, azylem i spokojem. Port to docelowa stacja, baza. Spokojny port to bezpieczne schronienie przed sztormem, to miejsce odpoczynku, pozbawienie się troski związanej z niebezpieczeństwami na morzu. Chryzostom przekłada właściwości i obraz portu na ubóstwo. W ten sposób przyciąga i zachęca słuchaczy do wyboru ubogiego stylu życia. Chcesz spokoju, żyj ubogo. Autor kończy życzeniem, abyśmy wszyscy wiedli życie spokojne i bezpieczne tu na ziemi, i dostąpili życia wiecznego w niebie, które jest doskonałym bezpiecznym portem.

\section{Człowiek chciwy podobny jest do cysterny, która nie wymienia wody}

Człowiek, który nie dzieli się swoimi bogactwami, podobny jest do cysterny, która nie wymienia wody na świeżą. To metafora skomponowana przez św. Ambrożego (339-397) w jego dziele pt. Historia

22 Homilia 90, 3: Mt 28,11-20, zob. tamże, s. 530.

23 Tamże. 
Nabota. Na czym polega dysponowanie swoim majątkiem według św. Ambrożego? Biskup Mediolanu mówił tak: „Cysterna bowiem, jeśli się nie odprowadza z niej wody, łatwo niszczeje, dlatego, że nie jest w użyciu i jest w nienaturalnym stanie. Jeśli natomiast używa się jej, ładnie wygląda, a woda staje się smaczniejsza do picia. Podobnie i wielkie bogactwo, jeżeli zgromadzi się je, jest jak piasek, jeżeli używa się go, nabiera blasku, lecz gdy leży spokojnie staje się bezużyteczne“. ${ }^{24}$ Dlatego Ambroży przypomina bogatym właścicielom ziemskim o ich podstawowym obowiązku: „Niech twój majątek nie czeka bezużytecznie, niech nie czeka na ciebie ogień wieczny. Oczekiwał cię będzie, jeśli nie usuniesz go czynami twego miłosierdzia“" ${ }^{25}$ Dla Ambrożego dobra same w sobie są czymś dobrym. Wszelkie byty i rzeczy stworzone są dobre, bo pochodzą od Stwórcy. Ocena moralna zależy od tego, w jaki sposób potrafi się nimi posługiwać człowiek, czy wykorzysta je do tego, by świadczyć dzieła miłosierdzia. ${ }^{26}$ Jałmużna jest piękna, czego nie trzeba uzasadniać. Oto, jak ją chwali nasz święty: ,Jałmużna zmywa, to co zbrudziła chciwość i plamę, jakie się nabawiłeś, porywając rzeczy cudze, oczyszczsz, rozdając rzeczy swoje“. ${ }^{27}$ Ambroży, stosując tę metaforę, zachęca do dzielenia się swoimi dobrami. Praktykowanie jałmużny skutkuje z religijnego punktu widzenia odpuszczeniem grzechów ofiarodawcy i jest świadectwem nawrócenia.

24 Św. A m b r o ż y, Historia Nabota, 52, tłum. i oprac. M. K o z e r a, Sandomierz 1985, s. 57.

25 Tamże, s. 58.

26 T. Koł o s o w s k i, Prawo do własności i sposób jej użytkowania w świetle „The Nabuthae Historia”'św. Ambrożego z Mediolanu, Vox Patrum 21(2001) 40-41, s. 242.

27 In Eccli. C. 3; cyt. za: J. C z u j, Caritas u św. Ambrożego (340-397), Caritas 4(1948)5, s. 156. 
Najlepsze miejsce do składowania bogactw na wieki to serca biednych ludzi, domy wdów i buzie biednych dzieci

„Swoje bogactwo - pisze Ambroży - przechowuj w sercu biedaków, gdzie nie zje go żaden wołek zbożowy, ani nie zepsuje się ze starości. Jako miejsce przechowania masz zanadrza biedaków, masz domy wdów, masz usta dzieci (...). Są to składy, które mogą przetrwać na wieki, są to spichlerze, których nie będzie w stanie nigdy rozsadzić przyszły urodzaj”. ${ }^{28}$ Ambroży nawiązuje tutaj do Ewangelii Łk 12,19. Wyjaśnia dalej, że obfitość dóbr stanowi wspólną własność. Bóg stworzył ziemię dla wszystkich ludzi, bogatych i biednych, którzy co do natury są sobie równi. ${ }^{29}$ Stwórca przekazał człowiekowi w dzierżawę bogactwa ziemi w tym celu, by bogaty, zgodnie z prawem natury, podzielił się z ubogim, który jest nie tylko współwłaścicielem, ale i dzieckiem natury. ${ }^{30}$ Ambroży utrzymuje, że ludzi biednych Bóg stworzył dla bogatych, aby mimo swych bogactw, byli w stanie zasłużyć sobie na zbawienie wieczne dzięki temu, że jałmużna zmywa wszelkie grzechy. ${ }^{31}$ Widzimy tutaj interesujący obraz spichlerzy, które gwarantują wieczną trwałość: serce biednych, usta dzieci, domy wdów. Właściciele majątków, rozdając wszelkie dobra ubogim oraz obdarowując hojnie, $\mathrm{z}$ radością i pokorą biednych, gromadzą w spichlerzach dobra duchowe. To one zapewnią im zbawienie i życie wieczne. ${ }^{32} \mathrm{I}$ w tym przypadku autor tworzy metaforę, która sama w sobie zachęca do działania.

\section{Dzielenie się bogactwami to święty handel}

Piotr Chryzolog (380-450), biskup Rawenny, wychodząc od rozważania $Ł k$ 12, 33, zwracał uwagę na idee tzw. świętego handlu

28 Św. A m b r o ż y, Historia Nabota, 37, s. 46-47.

29 T. K o ło s o w s k i, Prawo do własności, s. 243.

30 R. P a n k i e w i c z, Stosunek św. Ambrożego w „De Nabuthae” do wtasności i jałmużny, Vox Patrum 6(1986)11, s. 561.

31 Tamże, s. 562.

32 Tamże, s. 563. 
(w zamian za ziemską jałmużnę - wieczne zbawienie), zachęca do tegoż świętego handlu następująco: „Sprzedajcie to, co posiadacie i dajcie na jałmużnę (...) używajcie złych bogactw przez pośrednictwo miłosierdzia [jałmużny, dzielenia się rzeczami - uwaga K. M.], przekształcajcie w dobra boskie dobra ludzkie. Aby zaś nie zabrakło środka do przeniesienia tego, co pozostawiacie, został powołany ubogi; to ubodzy są tymi, którzy przenoszą wasze ciężary i zanoszą je chętnie, ponieważ nie są obciążeni takim ciężarem, lecz swobodni..."33 Człowiek przez jałmużnę ma przekształcać dobra ziemskie w dar dla nieba. Taki człowiek staje się handlarzem, który daje miłosierdzie. „Ten handlarz sprzedaje perły serca i ciała nie dla handlu ludzkiego, ale dla bożego. Wymieniając nie dla doraźnej korzyści, ale aby nabyć wieczną nagrodę (...), aby nabyć tę jedną perłę życia wiecznego". ${ }^{44}$ Piotr Chryzolog wykorzystuje do utworzenia metafory ubóstwa obrazy z codziennego handlu na rynku. Wszyscy wiemy, że jeśli chcemy coś kupić, musimy mieć pieniądze. Kaznodzieja wykorzystuje to doświadczenie i przenosi je na „kupno” życia wiecznego, nazywając to świętym handlem.

To, czego się pozbawiasz, staje się twoim zyskiem

Na kanwie historii Nabota św. Ambroży stara się uwrażliwić współczesnych mu ludzi na palące problemy społeczne. Zdaniem biskupa Mediolanu, obdarowywanie innych nie jest wcale szczególną hojnością lecz obowiązkiem. Dobra materialne mogą być czymś dobrym, jeżeli są należycie zużytkowane. Udzielając pomocy bliźnim, można zasłużyć na odpłatę samego Boga. Święty Ambroży stosuje tu celną metaforę, że strata może być zyskiem. Uczy, że „wszystko, co przekazałeś biedakowi, obraca się na twoją korzyść. Staje się twoim zyskiem to wszystko, czego się pozbawiasz. Żywisz się tym pokarmem, który dałeś biedakowi, gdyż na tym właśnie polega zysk,

33 P i ot r Chry zolog, Kazanie 25, 2; zob. Opere di san Pietro Crisologo (dalej: OSPC), t. 1, G. Banterle, Milano-Roma 1996, s. 196, 198; por. Łk 12, 33.

34 Te n ż e, Kazanie 47, 2; OSPC 1, s. 326; por Mt 13, 45-48. 
że kto jest miłosierny dla biedaka, sam żywi się. Miłosierdzie sieje się bowiem na ziemi, a wyrasta ono w niebie. Zasadza się go w biedaku, a pędy puszcza u Boga". ${ }^{35}$ Udzielanie pomocy prawdziwie potrzebującemu to nie strata, lecz wielki zysk duchowy. Jałmużna przynosi osobie wspierającej zysk duchowy. Jest bowiem pewnego rodzaju pożyczką, której procenty będzie wypłacał Bóg podczas sądu ostatecznego. ${ }^{36}$ Jeżeli jesteś hojny dla biedaka, to pożyczasz samemu Bogu (por. Prz 19,17). Na innym miejscu Ambroży mówi: „Z tego, co posiadasz, winieneś udzielać ubogiemu (...), ty ofiarujesz mu monetę, on otrzymuje życie, ty dajesz pieniądze (...) ubogi hojnie ciebie obdarza, ponieważ jemu zawdzięczasz zbawienie. Jeśli przyodziewasz nagiego, sam okrywasz się szatą sprawiedliwości (...), on ci pozyska przyjaźń świętych w przybytkach wiecznych. A wielka to łaska. Siejesz ziarno materialne, zbierasz owoce duchowe". ${ }^{37}$ To jałmużna nas oczyszcza i wybawia od śmierci (por. Tb 12, 9). Jeśli złożysz w sercu ubogiego jałmużnę, to ona będzie za tobą wstawiać się w dniu złym (por. Syr 29,15).

Podobny obraz metaforyczny w Kazaniu 25 zastosował Piotr Chryzolog, który nawoływał: „Sprzedajcie to, co macie i rozdajcie na jałmużnę.. (...) poprzez miłosierdzie wykorzystajcie nędzne bogactwa, przekształćcie w dobra Boże to, co należy do ludzi”. ${ }^{38}$ Człowiek ma odejść od chciwości i przez jałmużnę przekształcić dobra ziemskie w dar dla nieba. Kaznodzieja akcentuje, że to jałmużna staje się depozytem w niebie: „Zaskarb sobie wynagrodzenie przez darowizny na rzecz ubogich, ponieważ Ojciec niebieski przyjmuje w depozyt wszystko to, co otrzymuje ubogi....” Dalej woła: „Człowieku, zawierz Bogu to, co Bóg ci dał. On bowiem jako ofiarujący, jeśli jego wolą jest mieć dług u ciebie, zechce ci oddać więcej”. ${ }^{39}$ To

35 Św. A m broż y, Historia Nabota, 53, s. 58.

36 R. P a n k i e w i c z, Stosunek św. Ambrożego w „De Nabuthae” do własności, S. 563.

37 Św. A m broż y, Obowiąki duchownych, I, 11, p. 38-39, tłum. K. A b g a r o w i c z, Warszawa 1967, s. 32-33.

38 Pi ot r Chryzolog, Kazanie 25, 2; OSPC 1, s. 196; por Łk 12, 33.

39 Tamie, s. 198. 
czynne miłosierdzie wobec bliźnich jest wyrazem zaufania Bogu i zwróceniem Jemu jedynie długu. Posługując się tymi metaforami, autorzy proponują i zachęcają do troski o ubogich i praktykowania jałmużny aby przez to otrzymać życie wieczne z Bogiem.

\section{Człowiek jest administratorem dóbr, a nie ich właścicielem}

Piotr Chryzolog, uznawał prawo posiadania dóbr ziemskich. I dawał takie rozumowanie. Każdy człowiek jest śmiertelny. W związku $\mathrm{z}$ tym jest tylko administratorem dóbr, a nie ich właścicielem. Właścicielem jest sam Bóg - Stwórca Wszechświata. Co wyraził w Kazaniu 125: „Dobrze byłoby dla nas samych, abyśmy zastosowali opisane wydarzenia do siebie, my którzy musimy na ziemi czuć się administratorami, a nie uznawać się właścicielami; musimy być przekonani, iż pełnimy służbę o czasowym wymiarze i że nie nabyliśmy wiecznego prawa do posiadania". ${ }^{40}$ Śmiertelny człowiek nabywa tylko czasowe, a nie wieczne prawo posiadania rzeczy. Dlatego na ziemi winien dzielić się z innymi, a kryterium podziału majątkiem powinna być miłość, a nie idolatryczny kult pieniądza. Podobną metaforę zastosował w kazaniu św. Augustyn (354-430). Głosił, że jedynym właścicielem dóbr jest tylko Bóg, a nie człowiek, „gdyż nie część kupił lecz za całość dał cenę”. ${ }^{41}$ I tylko Bóg, jako właściciel „sądzić będzie okrąg ziemi w sprawiedliwości, a narody w prawdzie swojej". ${ }^{42}$ Augustyn, idąc za przekazem biblijnym (Łk 16,11-12), stwierdza, że to, co człowiek ma w doczesności, nie jest prawdziwą jego własnością, bo nie zaspokaja najgłębszych potrzeb duszy i nie daje pewności posiadania, bo z chwilą śmierci człowiek traci dobra doczesne. ${ }^{43}$ Stosując tę metaforę, autorzy uważają, że dobra mogą stać się prawdziwą

40 Te n ż e, Kazanie 125,11; OSPC 3, s. 14; por. Łk 16, 1-9.

${ }_{41}$ Objaśnienie Psalmu 95,15 - kazanie, zob. Św. A u g u s t y n, Objaśnienia Psalmów. Ps 78-102, tłum. J. S u low s k i, PSP 40, Warszawa 1986, s. 277.

42 Tamże, s. 279.

43 Te n ż e, Kazanie 50, zob. A. E c k m a n n, Bogactwo i ubóstwo w pismach świętego Augustyna, w: L. K o s t u c h, K. R y s z e w s k a (red.), Zbyteki ubóstwo w starożytności i średniowieczu, Kielce 2010, s. 259. 
drogą prowadzącą do uświęcenia, pod warunkiem że człowiek, jako ich administrator, kierować się będzie miłością bliźniego oraz będzie dostrzegał potrzebujących i udzieli im skutecznej pomocy.

\section{Spadek jest jak macocha}

W jednej z homilii Piotr Chryzolog przyrównuje spadek materialny do macochy. Mówi: „To jest macocha dla dzieci, a nie bogactwo”. ${ }^{4}$ Przybrana matka uważana jest stereotypowo za surową i nieżyczliwą. Traktuje nieswoje dzieci źle i niesprawiedliwie. „Wzbogaca dzieci tak naprawdę ten, kto im pozostawia doskonałą miłość". ${ }^{45}$ Kaznodzieja wyjaśnia w tej homilii, że „spadek ziemski wzbudza kłótnie wśród spadkobierców przed rozdaniem bogactw; przed podziałem dóbr, dzieli samych spadkobierców przed przyznaniem pojedynczym osobom części im należnej, dzieli samych spadkobierców i umieszcza ich na pozycjach przeciwstawnych. Dlatego nie jest to dziedzictwo, ale walka" ${ }^{46}$ Spadek to kłopot, a dzielenie go to sprawa drażliwa. Spadek rodzi nienawiść i kłótnie. Często dochodzi do niesnasek rodzinnych i waśni. Z kłótni powstaje wrogość, a z wrogości żądza zemsty. Każda kłótnia pochodzi z chciwości, $\mathrm{z}$ nienawiści i z próżności. ${ }^{47}$ Kłótnie o pieniądze potrafią ranić i wyzwalają silne emocje. Często kochające się rodzeństwo czy wspierający krewni nagle z powodu spadku stają się zaciekłymi wrogami i ujawniają swoje najgorsze cechy. Śmiertelny człowiek nabywa tylko czasowe, a nie wieczne, prawo posiadania dóbr. Dlatego na ziemi winien dzielić się z innymi a kryterium podziału majątkiem powinna być miłość. ${ }^{48}$

${ }^{44}$ Pi ot r Chryzolog, Kazanie 162, 3; OSPC 3, s. 264; por. Łk 12, 13.

45 Tamże.

46 Tamże.

47 Homilia na temat Listu do Filipian 4,4-9, zob. J a n C h r y z o s to m, Homilie i kazania wybrane, PSP 8, tłum. W. K a n i a, Warszawa 1971, s. 77.

48 D. K a s p r z a k, Zagadnienie posiadania dóbr materialnych $w$ kazaniach świętego Piotra Chryzologa, biskupa Rawenny, w: L. K o s t u c h, K. R y s z e w s k a (red.), Zbytek i ubóstwo w starożytności i średniowieczu, s. 282. 


\section{Bogacz jest jak pies, który szczeka}

Jan Chryzostom za pomocą metafory wściekłego psa, przywiązanego przy grobie, przedstawia bogacza. Jest on „nędzniejszy od niewolnika”, gdyż myśli ,jedynie o pieniądzach, procentach, pożyczkach, zyskach, brudach, szachrajstwach”. Nie słyszy niczego, bo jego ,serce jest przywiązane do majątku”. Charakteryzuje takiego nędznika: „Będziesz skuty żądzą bogactw silniej niż jakimkolwiek łańcuchem, będziesz szczekać na wszystkich, którzy zbliżą się do ciebie, czyniąc tylko to jedno, chcąc zachować dla siebie majątek". ${ }^{49}$ Jeśli posiadamy bogactwa, majątek to stajemy się jak pies, który szczeka na ludzi i atakuje ich, ponieważ broni swoich rzeczy. ${ }^{50} \mathrm{~W}$ tym kontekście alegoria jest wyszukana. Pies oznacza tutaj negatywne ludzkie zachowania. Bogacz - chciwiec - warczy jak pies (Ps 59,7), ujawniając swoją wściekłość. W innej homilii Chryzostom kreśli obraz chciwca. Jego „twarz składa się z psa i wilka. Nie mówi jak ludzie, lecz wydaje głos ponury, nieprzyjemny i straszny". ${ }^{51}$ Takiego człowieka porównuje do dzikiego zwierza, z którego oczu bucha płomień. Zamiast rąk ma węże zwieszające się z obu ramion. Ma usta, ale zamiast zębów tkwią ostre miecze, zamiast języka - źródło tryskające jadem i zgubną trucizną. Brzuch to piec rozżarzony. Jego nogi są szybsze niż jakikolwiek płomień. Nadto człowiek taki zabija przechodniów i żywi się ich mięsem..$^{52}$ Posługując się tą metaforą, autor wyraża mądrość, że człowiek przywiązany do rzeczy ziemskich zatraca godność i wolność ludzką a nawet może stracić dobra niebieskie, bo gdzie jest jego skarb, tam będzie i serce jego (Mt 6, 21).

49 Homilia 20, 3: Mt 6,16-23, zob. J a n C h r y z o s to m, Homilie na Ewangelię wedtug św. Mateusza, cz. I, 1-40, ŹMT 18, tłum. J. K r y s t y n i a c k i, Kraków 2000, s. 259.

50 D. B r a k k e, Care for the Poor, Fear of Poverty, and Love of Money: Evagrius Ponticus on the Monk's Economic Vulnerability w: S. R. Hol m a n (red.), Wealth and Poverty in Early Church and Society, Grand Rapids 2008, s. 79.

${ }_{51}$ Homilia 28, 5: Mt 8,23-34, zob. J a n C h r y z o s t o m, Homilie na Ewangelie wedtug św. Mateusza, cz. I, 1-40, s. 344

${ }^{52}$ Tamíe. 
Bogactwa są jak ładunek, który zatapia przeładowany statek

Ewagriusz z Pontu (345-399) w ascetycznym piśmie do zakonników $O$ ośmiu duchach zła podejmuje krytykę ośmiu wad, które nazywa namiętnościami. Czyni to za pomocą „,zrozumiałych przysłów”. Autor, aby ubarwić dzieło, używa metafory statku. „Bogaty mnich jest statkiem obładowanym, który przy wzburzeniu fal łatwo tonie. Jak bowiem przeciążonym okrętem miota każda fala, tak majętny zostanie zalany przez [swoje troski]". ${ }^{53}$ Człowiek, który traktuje życie mnisze jak okazję do gromadzenia pieniędzy, bardzo szybko stanie się podatny na inne pokusy i upadnie, gdyż jego umysł zniewalają troski, a nie modlitwa. Nimi się cieszy i w celu ich pomnożenia ciężko pracuje, zaniedbując praktykowanie ubóstwa. ${ }^{54}$ „Kto miłuje pieniądz, nie zdobędzie poznania, a kto je gromadzi, zostanie pogrążony w ciemności". ${ }^{55}$ Taki człowiek, oddany namiętnościom i dążący do pozyskania dóbr ziemskich, niczym przeładowany statek zmierza do niechybnej katastrofy i wkrótce zostaje zatopiony. Ewagriusz, stosując tę metaforę, wyraził tutaj przekonanie, że pokładanie ufności w pieniądzach, a nie w Bogu, jest nie do pogodzenia z życiem zakonnym.

Biedni są wolni, aby wznosić się jak orły

Ewagriusz z Pontu głosi pochwałę ubóstwa. Metafora orła jest dla niego trafnym rozwiązaniem. Autor porównuje ubogiego do orła symbolu siły i wytrwałości. Ubogi, tak jak ten potężny, wolny ptak, wyznacza sobie drogi na niebie (por. Prz 30,19). Jego właściwością jest nieustraszony, wysoki lot. „Ubogi mnich jest orłem lecącym

53 Ewagriusz z Pont u, O ośmiu duchach zła, tłum. L. Ni eś c i o r, w: te n ż e, Pisma ascetyczne, t. 1, ŹMT 18, Kraków 1998, s. 385.

54 L. M i s i r c z y k, Osiem logismoi w pismach Ewagriusza z Pontu, Kraków 2007, s. 245.

55 Ewagriusz z Pontu, Do mnichów mieszkajacych we wspólnotach, tłum. M. G r z el a k, w: t e n ż e, Pisma ascetyczne, t. 1, s. 287. 
wysoko, spada na swoją ofiarę wtedy, kiedy konieczność go zmusi. Tak stoi wyżej ponad wszelką pokusą. Gardzi tym, co doczesne, i unosi się w górę. Odsuwa się od tego, co ziemskie, a obcuje z tym, co w górze". ${ }^{56}$ Biedny niczym orzeł ma „lekkie skrzydła, nie obciążone zmartwieniami”. Może wzbijać się wysoko, wznosić się na skrzydłach i latać w powietrzu, przebijać się przez wichry i burze gdyż „żadną ziemską więzią nie przywiązał duszy". ${ }^{57}$ Ubogi mnich, który wyzwolił się z posiadania bogactwa, ale również z myśli o nim, jest wewnętrznie wolny i szczęśliwy. Wewnętrzna wolność jest znakiem rozumnego korzystania $z$ dóbr i prawdziwego posiadania. Ubogi mnich, ponieważ zaufał Panu, obfituje zawsze w dobra materialne i jest bogaty, gdyż ma rzeczy konieczne do codziennego życia. Bóg daje mu wszystko w obfitości. Dzięki temu, odzyskuje siły i otrzymuje skrzydła jak orzeł (por. Iz 40, 31). Taki styl życia jest zgodny z Ewangelią i szybko prowadzi go do wyzwolenia się z pozostałych namiętności. ${ }^{58} \mathrm{~W}$ ten sposób Ewagriusz domaga się wolności i czujności w używaniu dóbr doczesnych oraz zachęca do praktykowania ubóstwa, gdyż taka postawa czyni życie wolnym.

Troska o bogactwa jest jak łańcuch, który powstrzymuje psa od swobodnego biegania

Ewagriusz z Pontu we wskazówkach adresowanych do mnichów porównuje ogarniętego przez chciwość mnicha do psa uwiązanego na łańcuchu, który stracił wolność na rzecz zniewalającej go troski o posiadanie pełnej miski. „Bogatego zaś przygniatają troski i uwiązany jest jak pies na łańcuchu". ${ }^{59}$ Łańcuch to szereg połączonych ze sobą metalowych ogniw. Każde ogniwo odpowiada egzystencji skrępowanej. Łańcuch jest tutaj symbolem niewoli i więzi psychicznej.

56 Ewagriusz z Pont u, O ośmiu duchach zła, s. 385.

57 Tamże, s. 386.

58 L. M i s i a r c z y k, Osiem logismoi, s. 246.

59 Ewagriusz z Pontu, Do mnichów mieszkajacych we wspólnotach, s. 386. 
Ewagriusz słusznie podsumowuje, że najpierw demon zwodzi duszę, otaczając ją powoli i stopniowo myślami o chciwości i oddaje we władanie próżności. ${ }^{60}$ Następnie opanowany przez demona chciwy mnich staje się nienasyconym szaleńcem, u którego chciwość wzbudza nieustanny lęk o przyszłość, a przez to odbiera mu radość życia. ${ }^{61}$ Taki bogacz gromadzi coraz więcej, podnieca się coraz bardziej. Pragnie coraz więcej i wpada w coraz to nowy rodzaj szaleństwa chciwości. Stale nosi ze sobą wspomnienia bogactw, które stają się dla niego ciężkim brzemieniem i niepotrzebną zgryzotą. Dręczy masochistycznie swoją duszę jednocześnie pragnieniem ubóstwa i wspominaniem bogactwa. Cierpi i smuci się z tego powodu. ${ }^{62}$ Taki jest zawsze w pułapce, zawsze spętany, spętany własnymi występkami. ${ }^{63}$ Podobnie ujmuje bogacza Cyprian (200-258), gdy mówi: „Jesteś niewolnikiem i sługą pieniądza twego (...) jesteś skrępowany łańcuchami i więzami pożądliwości". ${ }^{4}$ Stosując tę metaforę, zarówno Cyprian jak i Ewagriusz przestrzegali przed taką postawą i motywowali słuchaczy do życia wolnego.

\section{Myśli o bogactwie są jak tunika, która przeszkadza atlecie w swobodnym biegu}

To kolejna metafora Ewagriusza z Pontu. Nieustanne myśli mnicha o bogactwie porównuje do szaty, która ogranicza go i przeszkadza w nieskrępowanym biegu. Autor pisze: „Z pewnością bowiem taki atleta zostanie powstrzymany przez szatę i da się bez trudu ciągnąć, podobnie jak umysł przez myśli pełne trosk". "Szata, niczym

${ }^{60}$ L. M i s i a r c z y k, Osiem logismoi, s. 251.

${ }^{61}$ Tamże, s. 246.

${ }^{62}$ Ewagriusz z Pont u, O ośmiu duchach zła, s. 386.

${ }_{63}$ R. P a n k i e w i c z, Stosunek św. Ambrożego w „De Nabuthae” do własności, S. 558.

${ }^{64}$ C y p ria n, O uczynkach i jałmużnach 13, w: t e n ż e, Pisma, I: Traktaty, tłum. J. C z uj, POK 19, Poznań 1937, s. 336.

${ }^{65}$ Ewagrius z z P o n t u, O różnych rodzajach złych myśli, tłum. L. N i e ś c i or, w: t e n ż e, Pisma ascetyczne, s. 335. 
głowa pełna myśli i trosk o bogactwie, utrudnia bieg „,ku nagrodzie, do jakiej Bóg wzywa nas", w górę (por. Flp 3, 14). Chciwy mnich zostaje opanowany przez wiele trosk związanych ze zdobyciem, pomnożeniem i przechowywaniem pieniędzy. Zatroskanie o bogactwa przeszkadza mu w oczyszczeniu swej duszy oraz poznaniu i miłości Boga. Nie doświadczy pokoju ducha ani poczucia bezpieczeństwa, ponieważ posiadanie pieniędzy nie jest w stanie go zapewnić. ${ }^{66} \mathrm{~W}$ innym miejscu autor akcentuje ubóstwo i kreśli obraz ubogiego mnicha, posługując się tym samym atletą: „Ubogi mnich jest atletą, który nie da się uchwycić w pół, i zwinnym biegaczem, który szybko pędzi ku nagrodzie". ${ }^{67}$ Autor tworzy metaforę, która jest przestrogą, żeby nie przeceniać ani przesadnie pragnąć bogactwa, gdyż w jego rozumieniu poddanie się myślom o bogactwie jest działaniem bezmyślnym i bezcelowym.

Prawdziwym biedakiem jest ten, komu brak sprawiedliwości, mądrości i roztropności

Grzegorz z Nyssy (330-390) mówi w Homiliach do błogosławieństw, że godne poszukiwania jest bogactwo cnót. „Ten, komu brak wstrzemięźliwości, cennego dobra sprawiedliwości, mądrości, roztropności lub [duchowych] innych skarbów, jest biedakiem i ubogim, nędznym i godnym litości, bo nie posiada nic wartościowego. Kto zaś dobrowolnie pozbył się tego, co uważa się za wady i niegodziwości, kto nie ma w swoich skarbcach żadnych diabelskich kosztowności, lecz płonie duchem i unika od zła, ten może być ubogim w sposób błogosławiony, wskazany przez Słowo, a owocem takiego ubóstwa jest właśnie królestwo niebios". ${ }^{68}$ Mamy tu do czynienia z odwróceniem tego, kto jest naprawdę bogaty. Autor zachęca do starania się o cnoty. Są one wielkim bogactwem. Pozbywając się

66 L. M i s i a r c z y k, Osiem logismoi, s. 245.

${ }^{67}$ Ewagriusz z Pont u, O ośmiu duchach zła, s. 386-387.

${ }_{68}$ Grzegor z z Nys s, Homilie do błogostawieństw, 1, tłum. M. P r z yc how s k a, ŹMT 34, Kraków 2005, s. 34-35. 
wad i niegodziwości, człowiek dalej pozostaje ubogi. Ubogi, ale starający się o cnoty, staje się bogatym w cnoty. Człowiek zostaje obsypany bardziej obfitymi dobrami aniżeli bogacz. Podobną myśl zawarł w Historii Nabota św. Ambroży: „Jeśli chcesz być bogatym, bądź ubogim na tym świecie, abyś był bogaty u Boga. U Boga bogaty jest ten, kto bogaty jest $\mathrm{w}$ wiarę, $\mathrm{w}$ miłosierdzie, $\mathrm{w}$ prostotę, w mądrość, w wiedzę". ${ }^{69}$

\section{Podsumowanie i wnioski}

W starożytnych homiliach Ojców Kościoła odkrywamy ich głębokiego ducha oraz umiejętności komunikacyjne i retoryczne. Wraz z nimi wchodzimy w świat bogatej metafory. „Dowodem na metaforyczność danego wyrażenia jest niewątpliwa konieczność jasnego pomyślenia o temacie i instrumencie nosicielu jako o dwu osobnych, ale zestawionych ze sobą przedmiotach" ${ }^{70}$ Świadomość tego, co chce wyrazić i powiedzieć komunikująca się osoba w konkretnej sytuacji, jest jedną z cech kompetencji komunikacyjnej. Prezentując postacie starożytnych kaznodziejów, których obrazy są zawarte w ich homiliach, można stwierdzić, że są oni mistrzami słowa i metafory nie tylko dla adresatów swoich kazań lecz także dla ludzi XXI w. Starożytni mówcy przemawiają sugestywnym językiem metafor, które uczą nas patrzeć i odsłaniać swój sekret. Ich twórczość wskazuje na właściwe wykorzystanie i użycie metafory do umiejętnego głoszenia słowa Bożego, biorąc pod uwagę kontekst kulturowy i sytuacyjny. Nadają swoim kazaniom widowiskowy charakter i dążą do pozyskania życzliwości audytorium. $\mathrm{Z}$ ich homilii emanuje ,wiara i nauka, mądrość i głęboka znajomość ludzi, wielkość ich ducha i charakteru, świętość i cnota”. Są dla współczesnego słuchacza „wyborną szkołą mądrości życiowej i praktycznego wyszkolenia". ${ }^{71}$

69 Św. A m b ro ż y, Historia Nabota, 60, s. 64.

70 K. P a r o ń, Rzeczywistość to metafora - próba kognitywnej analizy metafor $w$ felietonach Jerzego Urbana, Folia Litteraria Polonica 14, s. 43-53.

71 W. K r y n i c k i, Wymowa święta, Warszawa 1921, s. 278-279. 
Obecnie szukamy w kaznodziejstwie odpowiedzi na pytanie: Jak mówić, aby być słuchanym? Można ją znaleźć u Ojców. Ich homilie są mocno osadzone w realiach życia ówczesnego. Odtwarzają owe życie w wielu szczegółach, które w swoim czasie służyły do zobrazowania prawdy i wyprowadzenia z niej wniosków praktycznych. ${ }^{72}$ Dla nas ciekawy jest sposób ich mówienia. Mówią zwięźle i posługują się kunsztownym językiem metafor. Co możemy powiedzieć o tych metaforach z punktu widzenia retoryki i nowoczesnej komunikacji? Starożytni kaznodzieje tworzą trafną metaforę i właściwie jej używają. Służy ona do ozdobienia kazania i czyni je przyjemniejszym oraz praktycznym. Jednocześnie zachwyca i uwodzi odbiorców. Poszerza ich horyzonty i silniej działa. Sugestywna metafora niesie mocny ładunek emocjonalny i podnosi atrakcyjność przekazu. Wzmacnia przekaz, który jest krótki, prosty i zapadający w pamięć, przez co idealnie skupia uwagę człowieka. Metafora powoduje, że umysł człowieka koncentruje się na przekazywanej treści i odczytuje ukryte przesłanie oraz dociera do istoty przekazu. Metafora odgrywa w homiliach niebagatelną rolę. Kaznodzieje, stosując metaforę, znajdują klucz do serc współczesnych im ludzi. Potrafią dostrzec istotne egzystencjalne pytania słuchaczy i odpowiedzieć na nie słowem Bożym. Zanurzając się w tych metaforach, możemy nie tylko delektować się intelektualnie, lecz ich siła motywuje słuchaczy do działania i tym samym ma moc sprawczą.

Sama tematyka ubóstwa, a w tym samo ubóstwo stało się w chrześcijańskiej retoryce IV i V w. cnotą duchową i kategorią socjalną, a ubogi był utożsamiany z samym Chrystusem. Kluczem do odkrywania nauki Ojców Kościoła o ubóstwie jest zawsze sam Jezus, który dla nas stał się ubogi, aby nas swoim ubóstwem wzbogacić (por. 2Kor $8,9)$. To Syn Boga jest dla nas doskonałym ubogim Synem cieśli. Sam Bóg, Stwórca wszystkich rzeczy, staje się ubogim. I co? To stanie się ubogim jest sposobem Jezusa na wzbogacenie każdego człowieka.

72 W. W oj d e c k i, Homilie Ojców Kościoła a współczesne kaznodziejstwo polskie. Uwagi homilety, Ateneum Kapłańskie 92(1979)2, s. 278, 280. 
Co swoimi umiejętnościami retorycznymi komunikują nam starożytni kaznodzieje? Posługując się metaforami, Ojcowie Kościoła w swoich kazaniach krytykują chciwość oraz zachęcają do realizowania ideału rzeczywistego miłosierdzia i praktykowania filantropii. Czego uczą nas Ojcowie przez metafory? Metafory użyte i skomponowane przez nich są środkami, za pomocą których przekonują nas do tego, że ubóstwo, a najbardziej dzielenie się tym, co mamy, to najlepszy sposób na doświadczenie bogactwa, jakim jest Bóg i Jego miłość. Bogactwo duchowe ma większą szansę na pomnażanie wtedy, kiedy bogactwo materialne jest dzielone.

Czy starożytne metafory są aktualne? Tak, zgodnie z nimi, kiedy decydujemy się na ubóstwo w ich rozumieniu, to mamy większe szanse na doświadczanie w swoim życiu uczucia spokojnego portu, podziwu pięknej kobiety, satysfakcji z najlepszych miejsc na składowanie swoich bogactw, czyli serc biednych, domów wdów i ust dzieci. Mamy większe szanse na doświadczanie świętego handlu i zysku, na bycie administratorem dóbr, a nie ich właścicielem, na doświadczenie wolności, która niesie nas wysoko jak orła, a nie łańcucha, który krępuje psa, albo tuniki, która przeszkadza sportowcowi w swobodnym bieganiu.

\section{ks. Krzysztof MARCYŃSKI SAC}

Słowa kluczowe: Ojcowie Kościoła, starożytni pisarze wczesnochrześcijańscy, kompetencja komunikacyjna, komunikacja religijna, metafory, ubóstwo

Keywords: Ancient early Christian authors, Church Fathers, communicative competence, religious communication, metaphors, poverty 


\section{The Use of Metaphors as an Expression of Communicative Competence among the Chosen Early Christian Writers \\ Summary}

The ancient early Christian authors had a high level of communicative competence. This competence was expressed in their great artistry in oratory, writing and in their understanding the meaning of the communication contexts. To show and describe the communicative competence of the Church Fathers, the author of the present article focuses on the metaphors used by them. At the beginning, a metaphor as a rhetorical device is explained, in terms of what kind of function it has and how it works. In the second phase, the specific examples of metaphors that referred to poverty and wealth were chosen and their interpretations expounded. In the final section, the topic in question is summarized and then the conclusions come to are related to contemporary religious communication and the transmission of the faith in the digital world. 